\title{
FORENSIC ACCOUNTANT: INNATE TRAIT OR ACQUIRED SKILL?
}

\author{
Nada Arežina ${ }^{1}$, Goranka Knežević ${ }^{1}$, Nataša Simeunović ${ }^{2}$, Sofija Vukićević ${ }^{1}$ \\ ${ }^{1}$ Faculty of Business in Belgrade, Singidunum University, Belgrade, Serbia \\ ${ }^{2}$ Faculty for business economy, University Sinergija, Bijeljina, Republic of Srpska
}

\begin{abstract}
:
The recent wave of corporate fraudulent financial reporting demanded global reforms in corporate governance, as well as in financial reporting, in order to regain investors' trust. In current business environment, there is a high demand for forensic accountants because of their knowledge of different areas, including accounting, auditing, law and various investigative skills. However, the main dilemma is what skills forensic accountants should have and whether those are innate traits or skills that could be learned by experience. In this paper, we will try to sublimate the experiences and opinions of various authors in order to determine which skills and traits are relevant to the profession of forensic accountant. Furthermore, we will present the main results of research dealing with this issue, conducted by the American Institute of Certified Public Accountants (AICPA).
\end{abstract}

"Not all liars are fraudsters, but all fraudsters are liars" Joseph T. Wells

\section{INTRODUCTION}

Society's expectations changes in technological progress, as well as a series of accounting scandals in almost all sectors of economy, have imposed new and more rigid laws, in order to avoid their recurrence. The Adoption of the Sarbanes-Oxley Act (SOX) in 2002, in response to the fraud committed in the period between 1980 and 2000, as well as the foundation of Public Company Accounting Oversight Board (PCAOB) and the implementation of the Statement on Auditing Standards No. 99, have influenced the new approach in the audit processes, where the detection of fraud is of vital importance of vital importance. At present, in the complex business environment, there is a great demand for people who besides auditing, accounting and financial reporting, have knowledge in other areas, including legal regulations and laws, actuarial science, software tools, and even psychology. As forensic accounting represents the interdisciplinary field, it is considered that it has been placed in the forefront of the crusade against financial fraud and accounting scandals [1]. The level of this profession's high demand can be seen in the fact that when the American Institute of Certified Public Accountants - AICPA, formed a committee for certification in the area of financial forensics in June 2008; the goal was to award 900 credentials by the end of year one. However, until the end of September 2009, the AICPA had awarded more than 3,500 certifications, which is four times more than projected [2].

1 Certified Fraud Examiner (CFE), Certified Public Accountant (CPA) and Chairman of the Board of the Association of Certified Fraud Examiners (ACFE).

\section{FORENSIC ACCOUNTING AND ITS ROLE IN FINANCIAL INVESTIGATION}

The word forensic is derived from the Latin adjective forensic, which refers to one who is in the public square [3]. In ancient Rome, forum or square was the place where various commercial and state affairs, debates, and often trials were performed. The person, who would have been accused of a crime, had to appear in front of a group of individuals in the forum and together with the person who had accused him, answer to the questions about the allegations.

For more precise definitions of forensic accounting, many authors provide their interpretations, thus in the literature, various definitions of this term could be found. The authors Bologna and Lindquist define forensic accounting as a general term used to describe any financial investigation that could result in the judicial proceedings [4]. Williams states that forensic accounting represents a certain type of professional expertise, which is supported by features that can be clearly identified as rationality, objectivity and independence. The aforementioned author states that forensic accountants have particular social recognition, which is crucial to the economic issues and its translation into trust [5].

T. Singleton and Singleton A. believe that the term "forensic" in accounting refers to the relation and implementation of financial items in legal problems, therefore the evidence in forensic accounting is related to the court [6]. Over time, the court proceedings began to apply knowledge from other scientific fields, so today forensics has become an interdisciplinary field using different scientific achievements and knowledge, with the aim of assisting in delivering unbiased, substantiated and fact-based court judgments [7]. 
Considering the variety of services provided by forensic accounting, different authors use a wide range of activities that forensic accountants conduct in order to examine the financial, but also non-financial information for the clarification of disputed facts. Kahan, Manning and Wells state that forensic accountants, by using financial information, can understand, interpret and distinguish the important from the insignificant, as well as can reconstruct, identify, preserve, report and testify financial information obtained in the process of investigating fraud in court [8], [9] and [10]. Forensic accountants often analyze financial statements through various indicators such as: financial ratios, horizontal and vertical analysis of financial statements, data-mining techniques like Benford's Law and many others. The Member of the AICPA and professor, Dahli Gray, indicates that forensic accountants provide services in civil proceedings in respect of different situations, including: commercial procurement, valuation of marital property in divorce proceedings, compensation claims, lost profits due to fraud and other illegal acts, defraudation of taxes and money laundering techniques [11]. Wells believes that investigation skills and research mentality should also adorn the forensic accountant, but many years of experience working on complex fraud cases in law implementation provide priceless knowledge and experience [12].

Although forensic accounting involves performing a wide range of activities, in general, it can be divided into two broad areas: Investigative accounting and Judicial support [7]. As part of the Investigative accounting, there may appear Financial crime examination and Independent forensic audit, while Judicial support refers to consulting services, expertise and other services.

\section{LEGAL AND ECONOMIC ASPECTS OF FORENSIC ACCOUNTING}

Criminal activities represent an attack on basic social values and goods. Economic criminality as a specific type of criminal act, has all characteristics of criminality and can be seen as a concrete criminal occurrence, which took place in the past, while its detection and proving come later, through reconstruction based on indications and evidence [13]. The increase in crime is one of the basic social disorders, which manifests in the crisis of the legal system and morality and represents a significant economic burden to the society [14].

The global report of the Association of Certified Fraud Examiners (ACFE), which includes the analysis of 1,483 occupational fraud cases in more than 100 countries, according to the respondents, estimates that a typical legal entity loses $5 \%$ of its revenue each year due to criminal acts committed in the organization [15]. Misappropriation of assets occurs in 85\% of cases, with a median loss of 130,000 dollars. In contrast, only $9 \%$ of the cases related to fraud in the financial statements, although these cases, according to the survey, have the greatest financial impact, with an average loss of 1,000,000 dollars. Although external audits were conducted in many organizations, they proved to be the least effective method of control against fraud. External audit detected the fraud only in 3\% of cases, compared with $7 \%$ of cases which were detected incidentally. Thus, although the independent audit plays a vital role in organizational management, the results suggest that it should not be seen as a primary mechanism for detecting fraud in financial reporting. Furthermore, with the increasing number of laws and regulations, their frequent changes, together with the increase in the complexity of criminal activity in legal entities, there is a need for further development of forensic accounting and forensic auditing. The ACFE as an international organization offers people interested in the field of forensic accounting, various programs and training, such as the certification for Certified
Fraud Examiner - CFE, while the AICPA offers the certification for Certified in Financial Forensics - CFF intended for the Certified Public Accountants specialized for forensic accounting.

Regarding the countries in our region, in the Republic of Srpska, in 2012 there was introduced a new professional title of Certified Forensic Accountant, while in the Republic of Croatia this title was introduced in 2009. Unfortunately, so far, in the Republic of Serbia, in 2011 there was introduced only a course of forensic accounting in financial investigations for prosecutors, organized by the Organization for Economic Co-operation and Development (OEEC) in Serbia and the Ministry of Justice of the United States. This course was aimed to improve the work of the Prosecutor's Office, through the analysis of financial data, as well as gathering information on money laundering, corruption or other criminal acts of economic crime [16]. Taking into account the experience of neighbouring countries, as well as the current economic situation in the region, we believe that Serbia should take the initiative and introduce the aforementioned titles, in order to strengthen the mechanism against financial fraud.

\section{CHARACTERISTICS AND SKILLS OF FORENSIC ACCOUNTANTS}

The survey, conducted in 2009 by the AICPA, was aimed to improve the efficiency of forensic accounting, through the identification of the knowledge and skills that are necessary for this profession. The study included 126 attorneys, 603 certified public accountants, who primarily work as forensic accountants, and 50 academics, namely professors in the accounting and auditing department.

Respondents gave their opinions regarding the personality traits and characteristics that forensic accountants should own and ranked them according to the level of importance. In table 1 , we can see that all the three groups of respondents placed the analytical traits as the fundamental characteristics necessary for this profession, while in the second position, depending on the group of respondents, they highly ranked ability to focus on details, ethics and curiosity. This study confirmed the observations of Messmer's from 2004, which stated that analytical traits are fundamental for profession of forensic accountants [17]. Furthermore, academics and certified public accountants emphasize the scepticism, while attorneys gave more importance to responsiveness.

Besides the aforementioned personality traits and characteristics, the research also included the importance of core skills, which forensic accountants should possess (Table 2). All the three groups of respondents (attorneys, academics and public accountants) highly ranked skills such as: simplifying the presentation of information, auditing and written communication skills.

Similar results are provided by authors like Singleton, stating that the clear presentation of the findings derived from the investigation in expert witnessing, in fact represents public speaking. Thus, a forensic accountant should have good rhetorical skills, as well as the ability to present information briefly and in a manner understandable to an average citizen, who is not an expert in that particular field.

In addition, various authors state that, a feature that turns a well-trained and experienced professional accountant into a good financial investigator is the possession of "the sixth sense", i.e. good intuitive sense or intuitive research. This survey also covered the issues such as the ability of intuitive thinking, but in terms of whether it can be taught or learned from experience. The results showed that all the three groups of respondents believe that intuitive thinking is acquired through experience, and the more knowledge and experience the individual possesses, the greater the ability of intuitive development is. 
Attorney

Rank

Academic

Rank

CPA

Rank

\begin{tabular}{|c|c|c|c|c|c|c|}
\hline Analytical & $78 \%$ & 1 & $90 \%$ & 1 & $86 \%$ & 1 \\
\hline Detail-oriented & $64 \%$ & 2 & $35 \%$ & & $49 \%$ & 3 \\
\hline Ethical & $60 \%$ & 3 & $65 \%$ & 2 & $49 \%$ & 3 \\
\hline Responsive & $41 \%$ & 4 & $2 \%$ & & $10 \%$ & \\
\hline Insightful & $39 \%$ & 5 & $29 \%$ & & $24 \%$ & \\
\hline Inquisitive & $22 \%$ & & $48 \%$ & 4 & $52 \%$ & 2 \\
\hline Intuitive & $26 \%$ & & $40 \%$ & & $38 \%$ & 5 \\
\hline Persisent & $19 \%$ & & $46 \%$ & 5 & $30 \%$ & \\
\hline Skepticism & $12 \%$ & & $54 \%$ & 3 & $43 \%$ & 4 \\
\hline Evaluative & $30 \%$ & & $15 \%$ & & $16 \%$ & \\
\hline Function well under pressure & $28 \%$ & & $23 \%$ & & $35 \%$ & \\
\hline Generare new ideas and scenarios & $27 \%$ & & $10 \%$ & & $16 \%$ & \\
\hline Confident & $24 \%$ & & $10 \%$ & & $20 \%$ & \\
\hline Makes people feelat ease & $13 \%$ & & $17 \%$ & & $9 \%$ & \\
\hline Team player & $10 \%$ & & $4 \%$ & & $5 \%$ & \\
\hline Adaptive & $8 \%$ & & $13 \%$ & & $20 \%$ & \\
\hline Other & $8 \%$ & & $20 \%$ & & $6 \%$ & \\
\hline
\end{tabular}

Table 1: Essential Traits and Characteristics of Forensic Accountants [2].

$\begin{array}{lllll}\text { Attorney Rank } & \text { Academic } & \text { Rank } & \text { CPA }\end{array}$

\begin{tabular}{|c|c|c|c|c|c|c|}
\hline Effective oral communicator & $61 \%$ & 1 & $28 \%$ & & $43 \%$ & 3 \\
\hline Simplify the information & $57 \%$ & 2 & $11 \%$ & & $30 \%$ & \\
\hline Critical/strategic thinker & 495 & 3 & $62 \%$ & 1 & $50 \%$ & 1 \\
\hline Identify key issues & $38 \%$ & 4 & $30 \%$ & & $32 \%$ & \\
\hline Auditing skills & $37 \%$ & 5 & $53 \%$ & 2 & $31 \%$ & \\
\hline Investigative ability & $37 \%$ & 5 & $45 \%$ & 3 & $41 \%$ & 4 \\
\hline Effective written communicator & $21 \%$ & & $34 \%$ & & $43 \%$ & 2 \\
\hline Investigative intuitiveness & $24 \%$ & & $36 \%$ & & $39 \%$ & 5 \\
\hline Synthesize results of discovery and analysis & $37 \%$ & & $43 \%$ & 4 & $36 \%$ & \\
\hline Think like the wrongdoer & $4 \%$ & & $38 \%$ & 5 & $14 \%$ & \\
\hline Understand the goal of a case & $33 \%$ & & $9 \%$ & & $19 \%$ & \\
\hline Tell the story & $30 \%$ & & $9 \%$ & & $16 \%$ & \\
\hline See the bis picture & $30 \%$ & & $21 \%$ & & $30 \%$ & \\
\hline Organize an unstructured situation & $28 \%$ & & $32 \%$ & & $34 \%$ & \\
\hline Solve unstructured problems & $7 \%$ & & $30 \%$ & & $31 \%$ & \\
\hline Research skills & $6 \%$ & & $21 \%$ & & $10 \%$ & \\
\hline Solve structured problems & $2 \%$ & & $0 \%$ & & $2 \%$ & \\
\hline Other & $0 \%$ & & $2 \%$ & & $2 \%$ & \\
\hline
\end{tabular}

Table 2: Core Skills of Forensic Accountants [2]

\section{CONCLUSIONS}

The results of the research conducted by the AICPA indicated that attorneys, academics, and certified public accountants, highly ranked analyticity, ethics and curiosity, as traits that forensic accountants should have, but they considered equally important skills that are acquired through experience, including critical thinking, public speaking and simplifying complex information. The opinions of various authors emphasize that intuitive thinking should not be ignored, when it comes to the characteristics of forensic accountants, which was also confirmed by the aforementioned survey. However, the respondents consider intuition as an ability that is acquired and developed through experience. Moreover, through experience, forensic accountants complement and enhance their personal traits, while at the same time develop their intuitive abilities and improve the quality of investigative work. We believe that the synergies of the mentioned traits, skills, knowledge, as well as experience, improve the quality of forensic accountants work. Nevertheless, through the future similar research in countries in the region, this issue can be further examined and new insights related to this highly demanded profession can be given.

\section{REFERENCES}

[1] Bhasin, M. (2013) Corporate Governance and Forensic Accountant: an Exploratory Study Journal of Accounting Business \& Management, 20 (2), pp. 55-83.

[2] AICPA (2009) Characteristics and Skills of the Forensic Accountant, (access 05. 09. 2014), [available on site http://www.aicpa.org/InterestAreas/ForensicAndValuation/Resources/PractAidsGuidance/DownloadableDocuments/ForensicAccountingResearchWhitePaper.pdf] 
[3] Bošković, M. (1999) Kriminološki rečnik. Novi Sad: Matica Srpska.

[4] Bologna, J., \& Lindquist, R. (1995). Fraud Auditing and Forensic Accounting. New York: John Wiley and Soons.

[5] Williams, J. W. (2002) Playing the Corporate Shell Game: The Forensic Accounting and Investigation Industry, Law, and the Management of Organizational Appearences, doktorska disertacija, Toronto: York University.

[6] Singleton, T. W., \& Singleton, A. J. (2010) Fraud auditing and forensic accounting. New Jersey: John Wiley and Sons.

[7] Petković, A. (2010) Forenzčka revizija. Bečej: Proleter.

[8] Kahan, S. (2005) Bring' em back intact, Accounting Today, 19 (18), pp. 14-16.

[9] Manning, G. (2005) Financial Investigation and Forensic Acounting. Boca Raton: Taylor and Francis Group.

[10] Wells, J. (2005) When you suspect fraud. Journal of Accountancy, 199: pp. 82-85.

[11] Gray, D. (2008). Forensic accounting and auditing: compared and contrasted to traditional accounting and auditing. American Journal of Business Education, 1(2), pp. 115-126.
[12] Wells, J. (2011). Principles of Fraud Examination. New Jersey: John Wiley and Sons.

[13] Banović, B. (2002). Obezbeđenje dokaza u kriminalističkoj obradi krivičnih dela privednog kriminaliteta. Beograd: Viša škola unutrašnjih poslova.

[14] Ignjatović, Đ. (2011). Kriminologija. Beograd: Dosije.

[15] ACFE. (2014). Report to the Nations on Occupational Fraud and Abuse, (access 15. 09. 2014), [available on site http:// www.acfe.com/rttn/docs/2014-report-to-nations.pdf]

[16] Simeunović, N. i Lošić, S. Forenzičko računovodstvo kao sredstvo obezbjeđenja kvalitetnog finansijskog izvještavanja u cilju unaprijeđenja poslovnog ambijenta Republike Srpske (2013), XII Međunarodni Naučni skup Sinergija, Bijeljina, pp. 418-425

[17] Messmer, M. (2004). Exploring Options in Forensic Accounting. National Public Accountant, 5 (3), pp. 9-20.

\section{FORENZIČKI RAČUNOVOĐA: UROĐENA OSOBINA ILI VEŠTINA KOJA SE STIČE?}

\author{
Nada Arežina ${ }^{1}$, Goranka Knežević ${ }^{2}$, Nataša Simeunovićs ${ }^{3}$, Sofija Vukićević ${ }^{4}$ \\ ${ }^{1}$ Poslovni fakultet u Beogradu, Univerzitet Singidunum,Danijelova 32, Beograd, Srbija, narezina@singidunum.ac.rs \\ ${ }^{2}$ Poslovni fakultet u Beogradu, Univerzitet Singidunum, Danijelova 32, Beograd, Srbija, gknezevic@singidunum.ac.rs \\ ${ }^{3}$ Fakultet za poslovnu ekonomiju, Univerzitet Sinergija, Raje Baničića bb, Bijeljina, Republika Srpska, nsimeunovic@sinergija.edu.ba \\ ${ }^{4}$ Poslovni fakultet u Beogradu, Univerzitet Singidunum, Danijelova 32, Beograd, Srbija, svukicevic@singidunum.ac.rs
}

\section{Ključne reči:}

lažno finansijsko izveštavanje, istražne veštine, Američki institut ovlašćenih javnih računovođa. 